\title{
Effect of Different Rates of Poultry Manure and Bio-Slurry on the Yield of Solanum aethiopicum Shum
}

\author{
Mary Nanyanzi ${ }^{1}$, Elizabeth Balyejusa Kizito ${ }^{1}$, Michael Masanza ${ }^{1}$, Godfrey Sseruwu ${ }^{2} \&$ Moses Makoma Tenywa $^{3}$ \\ ${ }^{1}$ Department of Agricultural and Biological Sciences, Uganda Christian University, Mukono, Uganda \\ ${ }^{2}$ Mukono Zonal Agricultural Research and Development Institute, Mukono, Uganda \\ ${ }^{3}$ College of Agricultural and Environment Sciences, Makerere University, Kampala, Uganda \\ Correspondence: Mary Nanyanzi, Department of Agricultural and Biological Sciences, Uganda Christian \\ University, P.O. Box 4, Mukono, Uganda. E-mail: marynanyanzi8@gmail.com \\ Elizabeth Balyejusa Kizito, Department of Agricultural and Biological Sciences, Uganda Christian University, \\ P.O. Box 4, Mukono, Uganda. E-mail: lkizito08@gmail.com
}

Received: November 5, 2017

Accepted: February 10, 2018

Online Published: March 15, 2018

doi:10.5539/jas.v10n4p158

URL: https://doi.org/10.5539/jas.v10n4p158

\begin{abstract}
Poor soil fertility remains the major cause of low crop productivity on smallholder farms that are engaging in vegetable production in sub-Saharan Africa. Appropriate soil fertility regimes are therefore critical for improving crop productivity. Its yield has remained low mainly due to poor soil fertility. A field experiment in two different seasons was planted in a Completely Randomized Block Design using Solanum aethiopicum Shum (Nakati). The treatments were 3 sole fertilizer options applied at the following rates: poultry manure and bio-slurry manure at 5 , $10,15,20,25$ and $30 \mathrm{tha}^{-1}$, NPK (25:5:5) at the recommend application rate for tomato which is a sister crop and a control without any fertilizer. Crop budgets were used to determine the economic optimum rates of both sole applications of manure and combinations of manure with NPK. The sole applications and showed significantly $(\mathrm{p} \leq 0.05)$ increased the yield of $S$. aethiopicum compared with the control. The established biological optimum rates were at $24.19 \mathrm{t} \mathrm{ha}^{-1}$ and $21.51 \mathrm{t} \mathrm{ha}^{-1}$ for poultry manure and bio-slurry respectively. Using the crop budgets it was concluded that the established economic optimum rates were $20 \mathrm{t} \mathrm{ha}^{-1}$ and $10 \mathrm{tha}^{-1}$ for sole poultry manure and bio-slurry respectively. Recommendations for use of sole poultry manure and bioslurry at the rate of $20 \mathrm{tha}^{-1}$ and $10 \mathrm{tha}^{-1}$ respectively were made.
\end{abstract}

Keywords: soil fertility, poultry manure, bio-slurry, rates, yield, Solanum aethiopicum

\section{Introduction}

Soil fertility depletion is becoming a serious problem affecting agricultural productivity in Sub- Saharan Africa (SSA) (Bantiono, 2007). In Sub Saharan Africa however, high costs of inputs like fertilizers are a limitation to improving production of vegetables by small holder farmers (Ajayi, 2009). Studies in the central highlands of Kenya showed that approximately $80 \%$ of farmer households rely on use of organic inputs (Mugwe et al., 2007). In Uganda vegetable production for Solanacea vegetables especially Nakati (Solanum aethiopicum) is one of the most profitable enterprises in the region (Ssekabembe et al., 2002b), it is also highly constrained by soil fertility depletion. This is mainly as a result of increased soil erosion, leaching and continuous use of the land without replenishing its nutrients (Sanchez \& Jama, 2002).

In Uganda S. aethiopicum is ranked as the most important local vegetable species (Sseremba et al., 2017a) that is commercially grown, and is allocated larger land acreage than the others (Ssekabembe et al., 2003). It is grown by farmers in all regions with highest production in the central and eastern region due to high marketability (Ssekabembe et al., 2003; Sseremba et al., 2017a) and high nutrient content (Abolusoro et al., 2013). Under good management, farmers growing S. aethiopicum cultivars can get up to 75 leaf bundles of $30 \mathrm{~kg}$ each per $100 \mathrm{~m}^{2}$ meaning that the crop has a yield potential of $225 \mathrm{t} \mathrm{ha}^{-1}$. However, the average yield harvested during the dry season is only $30 \mathrm{tha}^{-1}$ (Lester \& Seck, 2004). This is largely due lack of adequate nutrient supply resulting from poor soil fertility (Sanchez et al., 1997; Bantiono, 2007).

A number of studies have been done on determining fertilizer and manure rates for other crops (Aminul, 2013; Ijoyah, 2009; Warnars \& Oppenoorth, 2014; Nompumelelo, 2008; Oyewole et al., 2012), but there is limited 
information on fertilizer regimes for S. aethiopicum production. There is a need for appropriate soil fertility regimes in S. aethiopicum, which are necessary for improved crop productivity. The main objective of the study was therefore to determine the optimum fertilizer rates for increased yield production of S. aethiopicum, Shum group (Nakati).

\section{Materials and Methods}

\subsection{Study Site}

The study was conducted on Uganda Christian University Skills Development Centre located in Ntaawo village, Mukono 3.5-4 km off Kampala Jinja highway. The site has an altitude of 1161 meters and its coordinates are Latitude $00^{\circ} 23^{\prime} \mathrm{N}$ and Longitude $32^{\circ} 44^{\prime} \mathrm{E}$. The Centre has an average temperature of $21.5^{\circ} \mathrm{C}$ and $1390 \mathrm{~mm}$ of rainfall per year. The field trial was conducted during April, 2015 and December, 2015. S. aethiopicum Shum group obtained was evaluated using poultry manure, bio-slurry, NPK (25:5:5) with $\mathrm{N}$ at a recommended for tomatoes $\left(0.04014 \mathrm{tacre}^{-1}\right)$ and a control without any fertilizer.

Before commencement of the trial, soil, bio-slurry and poultry manure samples were collected and taken to the Makerere University Soil, Water and Plant Analytical Laboratory to be analyzed for the physical and chemical properties indicated: $\mathrm{pH}$, Organic matter, Total Nitrogen $(\mathrm{N})$, available phosphorus $(\mathrm{P})$, potash $(\mathrm{K})$, calcium $(\mathrm{Ca})$ and magnesium $(\mathrm{Mg})$ plus microelements including manganese $(\mathrm{Mn})$, copper $(\mathrm{Cu})$, zinc $(\mathrm{Zn})$ and iron (Nompumelelo, 2008; United Kingdom Environment Agency, 2010). Soil samples were collected at a depth of $15 \mathrm{~cm}$ (topsoil) as described by Mbatha, (2008) following diagonal pattern across the entire field. The bio-slurry samples were collected from a 1000-L tank on delivery to the experimental site. 10 samples were collected with a $1 / 2$ Liter scoop cup into a bucket after stirring. All samples were mixed and about $150 \mathrm{ml}$ of this sample was put in the bottle. Poultry manure samples were collected from 5 different positions from a poultry manure heap and mixed together to make one uniform sample (United Kingdom Environment Agency, 2010).

\subsection{Experimental Layout}

The trial had two experiments. The planting materials used were $S$. aethiopicum seeds and it was assumed that seed used was of the same variety was made since pure stands have not been established.Treatments were replicated three times using a Completely Randomized Block Design (A. K. Gomez \& A. A. Gomez, 1984). Plants were spaced $30 \mathrm{~cm}$ between rows and thinned to $5 \mathrm{~cm}$ between plants two weeks after emergence (Ssekabembe \& Odong, 2009).

Properly decomposed and cool manure which had been stored for at least two to six month was used in the trial. Standalone applications were used in experiment one with poultry manure and bio-slurry applied at varying rates of $5 \mathrm{t} \mathrm{ha}^{-1}, 10 \mathrm{t} \mathrm{ha}^{-1}, 15 \mathrm{t} \mathrm{ha}^{-1}, 20 \mathrm{tha}^{-1}, 25 \mathrm{tha}^{-1}$ and $30 \mathrm{t} \mathrm{ha}^{-1}$ (Warnars \& Oppenoorth, 2014; Ijoyah \& Sophie, $2009)$ respectively. Further, the organic fertilizers were applied in combination with $25 \%$ of NPK (25:5:5) and $50 \%$ of NPK (25:5:5) in combination with all rates applied in the stand alone application rates above. Weeding was done using a hand hoe or by hand pulling of the weeds from the trials. Recommended plant protection measures such as spraying against pests and diseases was carried out two weeks and the crops were irrigated with water as and when required. The entire fertilizer requirement for the plot in both experiments was therefore applied in the first 30 days in order to enable the plants to utilize the manure. Poultry manure was split and applied twice. It was first applied a week before planting and the remaining manure applied again 20 days after emergence of $S$. aethiopicum plants. Bio-slurry was applied one week after crop emergence and the remaining manure at 20 days after the first application. Bio-slurry was diluted with water to a ratio of 1:3 to avoid scorching of the plants (Warnars \& Oppenoorth, 2014). NPK (25:5:5) was also split and applied twice one week after crop emergence and the remaining NPK at 20 days after the first application S. aethiopicum matures within 60-70 days or within 3 months (Ssekabembe et al., 2013).

\subsection{Data Collection and Analysis}

Data collection was carried out every two weeks on agronomic traits for growth and yield like plant height, number of leaves, leaf area, number of branches per plant, plant vigour, stem girth, total biomass, shoot biomass, root biomass and harvest index as earlier described by Sseremba et al. (2017a, 2017b, 2018) and Nakanwagi et al. (2018). The plant height was measured using a meter rule and the stem girth was determined using the thread and meter rule method (Amhakhian et al., 2010). The length of the leaf was measured from the tip of lamina to the point of insertion of the lamina and petiole along the midrib and the width was measured end to end between the widest part of the lamina perpendicular to the lamina midrib (Fallovo, 2008). Using the data for leaf length and width, leaf area was calculated using a regression equation:

$$
\mathrm{Y}=-10.12+0.834 \mathrm{X}
$$


where, $X=(L W) 0.5$ (Carmassi, 2007).

Visual plant vigour of the plants was also evaluated using a Scale of 1-5 where $1=$ plants which are small, chlorotic and non vigorous and $5=$ plants which are large, dark green and vigorous (McCarter et al., 1976; Sseremba et al., 2017b). Additionally total biomass in kilograms per plot, Shoot weight $(\mathrm{kg})$ (Marketable weight), and Root weight (kg) (Unmarketable weight) were measured using the Adams electronic weighing scale. This data was extrapolated to kg per acre and harvest index was calculated using the following formula:

$$
\mathrm{HI}=\frac{\text { Economic yield }}{\text { Biological yied }}-100
$$

In addition, a Cost Benefit Analysis associated with the use of poultry manure and bio-slurry was made. Crop budgets were the standard tools for the cost benefit analysis of fertilizer use (Ayodele \& Shittu, 2013; Tesfaw, 2013). Additional data were also obtained as follows:

i) Mean market price of S. aethiopicum from main markets in Mukono Municipality;

ii) Labour costs (Shillings per man-day);

iii) Total variable costs or total cost of production: cost of poultry manure and bio-slurry up to the farm gate plus Labour cost for application of the manure.

Total variable costs or Total cost of produce $=$

Price of PM and bio-slurry + cost incurred in buying + labor cost for application

The average marketable yield obtained from each treatment was recorded. The marketable yield from the control plots was taken as a reference and the yield increment at all rates of each type of manure (increase over the control) was taken.

$$
\text { Incremental yield }=\text { Yield at particular treatment }- \text { Control }
$$

$$
\text { Response rate }=\frac{\text { Incremental yield }}{\text { Manure rate applied }}
$$

The yield increment for each manure rate was multiplied by the price of $S$. aethiopicum to obtain its value.

$$
\text { Value of incremental yield }=\text { Incremental yield } \times \text { Price of } S \text {. aethiopicum }
$$

Deducting the incremental cost of production from this value gives the net income which is divided by the total cost to obtain the benefit cost ratio.

$$
\begin{gathered}
\text { Incremental profit }=\text { Value of incremental yield }- \text { Total variable costs } \\
\qquad \text { Value_Cost Ratio }=\frac{\text { Incremental profit }}{\text { Incremental (variable) costs }}
\end{gathered}
$$

\subsection{Data Analysis}

Data were entered in Microsoft excel. Means data for each plot and each treatment used in the study were calculated (Thorsen \& Woodward, 2010) and compared using the Duncan Multiple Range Test at 5\% significance level. Data that were not normally distributed were transformed using natural logarithm. Quadratic prediction using polynomial regression fits $\left(\mathrm{Y}=\mathrm{a}+\mathrm{bx}+\mathrm{cx}^{2}\right)$ for fertilizer rates with yield of $S$. aethiopicum were also made so as to determine optimum manure rates.

\section{Results and Discussion}

\subsection{Optimum Poultry Manure Rates for Production of S. aethiopicum}

The effect of the fertilizers was evaluated through performance of agronomic and yield traits such as plant vigour, stem girth, height, number of leaves, number of branches, leaf area, marketable yield and Harvest Index. The results obtained in this study are presented and discussed in detail in the following subsections. Table 1 shows the results for the effect of poultry manure on growth and yield parameters of $S$. aethiopicum at harvest. The results of the study showed that the poultry manure rates are capable of improving the yield of S. aethiopicum. Plants treated with poultry manures and NPK recorded higher value of vigour, stem girth, plant height, number of leaves, leaf area and number of branches than the control. The best plant vigour of $4.56 \pm 3.5$ was recorded for poultry manure at a rate of $15 \mathrm{tha}^{-1}$ followed by $4.39 \pm 0.9$ for poultry manure at the rate of $25 \mathrm{t} \mathrm{ha}^{-1}$. The least plant vigour was noticed more at $3.52 \pm 1.1$ was recorded for poultry manure at the rate of $25 \mathrm{t} \mathrm{ha}^{-1}$. The increase in vigour can be explained by availability of nutrients required for proper crop growth and development. $S$. aethiopicum plants treated with $25 \mathrm{t} \mathrm{ha}^{-1}$ had the biggest mean stem girth $(2.66 \pm 1.6 \mathrm{~cm})$ followed by plants treated with poultry manure at $15 \mathrm{t} \mathrm{ha}^{-1}(2.55 \pm 1.3 \mathrm{~cm})$. The least stem girth $(1.92 \pm 0.6 \mathrm{~cm})$ was recorded for the untreated control plants (Table 1). Significant differences were observed between the control and all treatments 
except $5 \mathrm{t} \mathrm{ha}^{-1}$, other differences were noted between NPK, $15 \mathrm{tha}^{-1}$ and $25 \mathrm{tha}^{-1}$. This may be due to the provision of all necessary macro-and micro-nutrients in available forms from the poultry manure, hence improving the physical and biological properties of the soil (Abou El-Maged et al., 2005).

Table 1: Mean effect of poultry manure (PM) rates on growth and yield parameters of S. aethiopicum

\begin{tabular}{|c|c|c|c|c|c|c|c|c|}
\hline Treatments & \begin{tabular}{|l|} 
Vigour \\
$(1-5)$
\end{tabular} & $\begin{array}{l}\text { Stem girth } \\
(\mathrm{cm})\end{array}$ & $\begin{array}{l}\text { Plant height } \\
\text { (cm) }\end{array}$ & $\begin{array}{l}\text { Number } \\
\text { of leaves }\end{array}$ & $\begin{array}{l}\text { Leaf area } \\
\left(\mathrm{cm}^{2}\right)\end{array}$ & $\begin{array}{l}\text { Number of } \\
\text { branches }\end{array}$ & $\begin{array}{l}\text { Marketable } \\
\text { yield }\left(\mathrm{kg} \mathrm{ha}^{-1}\right)\end{array}$ & Harvest index \\
\hline Control & $3.63 \pm 1.1^{\mathrm{ab}}$ & $\begin{array}{l}0.262 \\
(1.92 \pm 0.6)^{\mathrm{a}}\end{array}$ & $\begin{array}{l}0.973 \\
(10.54 \pm 5.2)^{\mathrm{a}}\end{array}$ & $\begin{array}{l}1.360 \\
(25.79 \pm 12.7)^{\mathrm{a}}\end{array}$ & $\begin{array}{l}1.60 \\
(49.05 \pm 29.42)^{\mathrm{a}}\end{array}$ & $\begin{array}{l}0.805 \\
(6.91 \pm 3.7)^{\mathrm{a}}\end{array}$ & $\begin{array}{l}1187.96 \pm \\
1095.0^{\mathrm{a}}\end{array}$ & $0.905 \pm 0.05^{\mathrm{a}}$ \\
\hline $\mathrm{PM}$ at $5 \mathrm{tha}^{-1}$ & $3.92 \pm 1.0^{\mathrm{bc}}$ & $\begin{array}{l}0.296 \\
(2.12 \pm 0.8)^{\mathrm{a}}\end{array}$ & $\begin{array}{l}0.990 \\
(11.54 \pm 6.7)^{\mathrm{ab}}\end{array}$ & $\begin{array}{l}1.466 \\
(38.70 \pm 30.0)^{\mathrm{bc}}\end{array}$ & $\begin{array}{l}1.65 \\
(58.60 \pm 38.35)^{\mathrm{ab}}\end{array}$ & $\begin{array}{l}0.869 \\
(8.74 \pm 6.6)^{\mathrm{c}}\end{array}$ & $\begin{array}{l}2681.60 \pm \\
2006.4^{\text {bc }}\end{array}$ & $0.917 \pm 0.06^{\mathrm{ab}}$ \\
\hline $\mathrm{PM}$ at $10 \mathrm{tha}^{-1}$ & $4.06 \pm 0.8^{\mathrm{cd}}$ & $\begin{array}{l}0.342 \\
(2.29 \pm 0.6)^{c}\end{array}$ & $\begin{array}{l}1.039 \\
(12.21 \pm 5.7)^{\mathrm{bc}}\end{array}$ & $\begin{array}{l}1.481 \\
(34.26 \pm 17.3)^{\mathrm{c}}\end{array}$ & $\begin{array}{l}1.74 \\
(63.07 \pm 29.15)^{\text {de }}\end{array}$ & $\begin{array}{l}0.889 \\
(8.50 \pm 3.6)^{\mathrm{bc}}\end{array}$ & $\begin{array}{l}2436.53 \pm \\
558.8^{\mathrm{b}}\end{array}$ & $0.926 \pm 0.02^{\mathrm{ab}}$ \\
\hline PM at $15 \mathrm{tha}^{-1}$ & $4.56 \pm 3.5^{\mathrm{e}}$ & $\begin{array}{l}0.375 \\
(2.55 \pm 1.3)^{\mathrm{d}}\end{array}$ & $\begin{array}{l}1.081 \\
(14.31 \pm 8.2)^{\mathrm{cd}}\end{array}$ & $\begin{array}{l}1.502 \\
(36.94 \pm 21.0)^{\mathrm{c}}\end{array}$ & $\begin{array}{l}1.73 \\
(63.59 \pm 34.92)^{\mathrm{cde}}\end{array}$ & $\begin{array}{l}0.921 \\
(9.04 \pm 6.0)^{\mathrm{c}}\end{array}$ & $\begin{array}{l}2878.05 \pm \\
924.0^{\text {bc }}\end{array}$ & $0.935 \pm 0.08^{\mathrm{b}}$ \\
\hline $\mathrm{PM}$ at $20 \mathrm{tha}^{-1}$ & $3.52 \pm 1.1^{\mathrm{a}}$ & $\begin{array}{l}0.332 \\
(2.26 \pm 0.7)^{\mathrm{c}}\end{array}$ & $\begin{array}{l}1.111 \\
(15.88 \pm 9.4)^{\mathrm{de}}\end{array}$ & $\begin{array}{l}1.456 \\
(34.54 \pm 23.9)^{\mathrm{bc}}\end{array}$ & $\begin{array}{l}1.71 \\
(62.63 \pm 37.48)^{\mathrm{bcd}}\end{array}$ & $\begin{array}{l}0.842 \\
(7.39 \pm 4.1)^{\mathrm{ab}}\end{array}$ & $\begin{array}{l}3701.13 \pm \\
1039.7^{\mathrm{c}}\end{array}$ & $0.931 \pm 0.01^{\mathrm{ab}}$ \\
\hline PM at $25 \mathrm{tha}^{-1}$ & $4.39 \pm 0.9^{\mathrm{de}}$ & $\begin{array}{l}0.392 \\
(2.66 \pm 1.6)^{\mathrm{d}}\end{array}$ & $\begin{array}{l}1.308 \\
(22.83 \pm 10.3)^{\mathrm{f}}\end{array}$ & $\begin{array}{l}1.464 \\
(33.59 \pm 18.8)^{\mathrm{bc}}\end{array}$ & $\begin{array}{l}1.78 \\
(69.61 \pm 34.92)^{\mathrm{e}}\end{array}$ & $\begin{array}{l}0.923 \\
(9.58 \pm 5.9)^{\mathrm{c}}\end{array}$ & $\begin{array}{l}3286.67 \pm \\
1177.4^{\mathrm{bc}}\end{array}$ & $0.915 \pm 0.03^{\mathrm{ab}}$ \\
\hline $\mathrm{PM}$ at $30 \mathrm{tha}^{-1}$ & $3.73 \pm 1.3^{\mathrm{abc}}$ & $\begin{array}{l}0.338 \\
(2.35 \pm 0.8)^{\mathrm{c}}\end{array}$ & $\begin{array}{l}1.139 \\
(18.39 \pm 12.8)^{\mathrm{e}}\end{array}$ & $\begin{array}{l}1.424 \\
(34.98 \pm 27.3)^{b}\end{array}$ & $\begin{array}{l}1.74 \\
(70.93 \pm 46.73)^{\mathrm{de}}\end{array}$ & $\begin{array}{l}0.884 \\
(9.20 \pm 7.9)^{\mathrm{c}}\end{array}$ & $\begin{array}{l}3341.77 \pm \\
879.0^{\text {bc }}\end{array}$ & $0.917 \pm 0.03^{\mathrm{ab}}$ \\
\hline NPK (25:5:5) & $3.89 \pm 1.1^{\mathrm{abc}}$ & $\begin{array}{l}0.327 \\
(2.36 \pm 1.2)^{\mathrm{bc}}\end{array}$ & $\begin{array}{l}1.027 \\
(13.24 \pm 9.3)^{\mathrm{abc}}\end{array}$ & $\begin{array}{l}1.495 \\
(37.12 \pm 23.7)^{\mathrm{C}}\end{array}$ & $\begin{array}{l}1.66 \\
(60.0 \pm 45.08)^{\mathrm{abc}}\end{array}$ & $\begin{array}{l}0.917 \\
(9.79 \pm 7.0)^{\mathrm{c}}\end{array}$ & $\begin{array}{l}3434.20 \pm \\
297.8^{\text {bc }}\end{array}$ & $0.936 \pm 0.01^{\mathrm{b}}$ \\
\hline Mean & 3.9598 & 0.333 & 1.083 & 1.356 & 1.701 & 0.881 & 2868.365 & 0.923 \\
\hline S.E.D. & 0.1750 & 0.016 & 0.028 & 1.45617 & 0.032 & 0.031 & 520.255 & 0.012 \\
\hline F. pr & $<0.001$ & $<0.001$ & $<0.001$ & $<0.001$ & $<0.001$ & $<0.001$ & 0.001 & 0.154 (NS) \\
\hline L.S.D. $(\alpha=0.05)$ & 0.1750 & 0.031 & 0.055 & 0.049 & 0.062 & 0.061 & 1062.502 & 0.025 \\
\hline Treatment*Season & 0.269 (NS) & $<0.001$ & $<0.001$ & $<0.001$ & $<0.001$ & $<0.001$ & 0.008 & 0.002 \\
\hline C.V. $\%$ & 39.8 & 42.8 & 23.2 & 15.6 & 16.7 & 22.14 & 31.4 & 2.3 \\
\hline
\end{tabular}

Note. Parameters which were not normally distributed have means of original data in brackets and means of transformed data outside the brackets, NS means not significant, Means with similar letters are not significantly different at $\mathrm{p} \leq 0.05$ based on the Duncan's Multiple Range Test.

As a result this availability affects crop growth parameters such as stem girth. Stem diameter would have positive implication on lodging, since thicker the stem, the less likely the plant would lodge as a result of, increased foliage fruit carriage or due to wind (Oyewole et al., 2012).

Highest mean plant height $(22.83 \pm 10.3 \mathrm{~cm})$ was recorded where plants treated with poultry manure at $25 \mathrm{t} \mathrm{ha}^{-1}$. This was followed by $30 \mathrm{t} \mathrm{ha}^{-1}$ with height of $18.39 \pm 12.8 \mathrm{~cm}$. However minimum plant height $(10.54 \pm 5.2 \mathrm{~cm})$ was observed in the control where the plants were treated with no manure. Mean plant height differed between the control and $15 \mathrm{tha}^{-1}, 20 \mathrm{t} \mathrm{ha}^{-1}, 25 \mathrm{tha}^{-1}$ and $30 \mathrm{tha}^{-1}$ and NPK differed from $25 \mathrm{t} \mathrm{ha}^{-1}$ and $30 \mathrm{t} \mathrm{ha}^{-1}$. However these results are lower than those reported by (Callistus \& Anthony, 2014) in Solanum nigrum. Nutrients contain in manures are reported to be released more slowly and stored for longer time in the soil ensuring longer residual effects, and improved root development (Abou El-Magel et al., 2005), which must have been responsible for the consistent better height performance obtained with manure application over inorganic treatment. Oyewole et al. (2012), stressed that the application of organic manure significantly increased crop growth and yield, and attributed this to high level of Nitrogen which is essential for plant growth. The highest mean number of leaves (38.70 \pm 30.0 leaves) at 12 was recorded where plants treated with $5 \mathrm{t} \mathrm{ha}^{-1}$ followed by $36.94 \pm 21.0$ leaves for $15 \mathrm{t}$ $\mathrm{ha}^{-1}$. However, lowest number of leaves $(25.79 \pm 12.7$ leaves $)$ was recorded for the control plants. None of the treatments indicated a drop in the number of leaves since the plants are harvested before they reached their physiological maturity. Number of leaves differed between the control and all treatments except $30 \mathrm{tha}^{-1}$. The differences may have been as a result of plants receiving more readily available nutrients from the decomposed poultry manure hence encouraging additional vegetative growth. Similar results were reported by (Sultana, 2006; Sarker, 2005; Islam et al., 2011). Highest leaf area of $70.93 \pm 46.73 \mathrm{~cm}^{2}$ which was recorded in plots treated with poultry manure at $30 \mathrm{t} \mathrm{ha}^{-1}$ followed by the plants treated with $25 \mathrm{t} \mathrm{ha}^{-1}$ which had $69.61 \pm 34.92 \mathrm{~cm}^{2}$. Control plants had the least leaf area of $49.05 \pm 29.42 \mathrm{~cm}^{2}$. Leaf area differed between the control and $10 \mathrm{t} \mathrm{ha}^{-1}, 15 \mathrm{t} \mathrm{ha}^{-1}$, $20 \mathrm{t} \mathrm{ha}^{-1}, 25 \mathrm{t} \mathrm{ha}^{-1}$ and $30 \mathrm{t} \mathrm{ha}^{-1}$. The highest mean number of branches of $9.58 \pm 5.9$ branches was recorded for 
plants treated with poultry manure at $25 \mathrm{t} \mathrm{ha}^{-1}$ followed by $9.20 \pm 7.9$ branches for $30 \mathrm{t} \mathrm{ha}^{-1}$ while the lowest number of branches (6.91 \pm 3.72 branches) was recorded for the untreated control plants (Table 1).

Results of marketable yield of $S$ aethiopicum as influenced by the poultry manure and the Harvest Index are also presented in Table 4 . The highest yield of $3701.13 \pm 1039.7 \mathrm{~kg} \mathrm{ha}^{-1}$ was produced by the application of poultry manure at the rate of $20 \mathrm{t} \mathrm{ha}^{-1}$ followed by poultry manure at the rate of $30 \mathrm{t} \mathrm{ha}^{-1}$ with $3341.77 \pm 879.0 \mathrm{~kg} \mathrm{ha}^{-1}$. Marketable yield was also least in control plots which had $1187.96 \pm 1095.0 \mathrm{~kg} \mathrm{ha}^{-1}$. Harvest index was highest $(0.935 \pm 0.08)$ in plots treated with poultry manure at the rate of $15 \mathrm{t} \mathrm{ha}^{-1}$ and least in control plots which had $0.905 \pm 0.05$. Significant differences $(p<0.05)$ were observed in the mean marketable yield for poultry manure treated plots and the control. Control results significantly differed from results for poultry manure at $15 \mathrm{tha}^{-1}, 20$ $\mathrm{t} \mathrm{ha}^{-1}, 25 \mathrm{t} \mathrm{ha}^{-1}$ and 30 but results for NPK did not significantly differ from poultry manure results. These results follow the same tread like those of Ijoyah and Sophie (2009) in cabbages but she got the best yield at $30 \mathrm{tha}^{-1}$. These results can be explained by the fact that organic manures especially poultry manure are said to improve soil fertility by increasing the number and diversity of soil microorganisms which enhances water and nutrient availability hence improved development and health of crops (Amanullah et al., 2010). However for the effect of different poultry manure treatments on harvest index of $S$. aethiopicum, significant differences $(p<0.05)$ were only observed between the control and poultry manure at $25 \mathrm{tha}^{-1}$ plus NPK. The lack of significant differences between the inorganic fertilizer and the organic fertilizer, may be attributed to the fact that decomposed poultry manure equally has available required plant nutrients like those in NPK. However unlike during production of $S$. aethiopicum which has a short growing season, if given more time for the mineralization of the nutrients that are there in the manure applied, poultry manure is capable of availing much more nutrients than those in NPK (Okoli \& Nweke, 2015).

The regression analysis of marketable yield as a dependable variable and poultry manure rates as the regressor showed the coefficient of multiple determinations $\left(\mathrm{R}^{2}\right)$ of $85.1 \%$ indicating that increase in yield of S. ethiopicum produced was significantly affected by poultry manure. Figure 1 indicated that largest yield responses to manure occur with the first increments of applied manure. At this stage gains in economic returns per $\mathrm{kg}$ of manure are also greatest. The returns are lower as the manure rate approaches the economic optimum (when the cost of additional manure is equal to the value of the associated yield increase. When the derivative of the quadratic equation for total yield $\mathrm{y}=-3.467 \mathrm{x}^{2}+167.8 \mathrm{x}+1396$ was solved, it resulted in a maximum poultry manure rate of $24.19 \mathrm{tha}^{-1}$.

The optimum poultry manure rate was therefore predicted to be at $24.19 \mathrm{tha}^{-1}$ which is between $20 \mathrm{tha}^{-1}$ and $25 \mathrm{t}$ $\mathrm{ha}^{-1}$ which were associated with higher stem girth, plant height, leaf area and yield respectively.

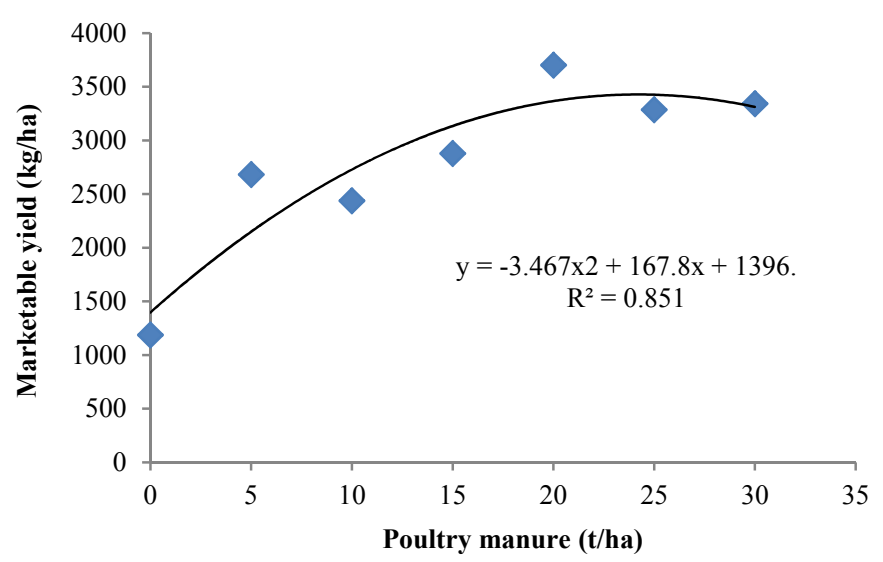

Figure 1. Effect of Poultry manure on the yield of S. aethiopicum

\subsection{Optimum Bio-Slurry Manure Rates for Production of S. aethiopicum}

Similar to poultry manure, the effect of bio-slurry was evaluated through performance of agronomic and yield traits such as stem girth, plant height, number of leaves, leaf area and number of branches. Table 2 shows mean effect of bio-slurry on growth and yield parameters of S. aethiopicum as explained below. Both the NPK and bio-slurry generally increased the growth and performance of $S$. aethiopicum. The best plant vigour $(4.09 \pm 1.0)$ 
was recorded for plants treated with bio-slurry manure at a rate of $25 \mathrm{t} \mathrm{ha}^{-1}$ followed by $4.03 \pm 0.9$ for plants treated with the rate of $15 \mathrm{t} \mathrm{ha}^{-1}$. The least plant vigour of $3.37 \pm 1.0$ was recorded for plants treated with bio-slurry at $10 \mathrm{tha}^{-1}$. The high vigour which represents large plants which are dark green in colour with use of manure that is more at a rate more than $15 \mathrm{t} \mathrm{ha}^{-1}$ can be explained by availability of nutrients required for proper crop growth and development since bio-slurry contains readily available nutrients, amino acids and bioactive substances needed for vegetable growth (Warnars \& Oppenoorth, 2014). Results showed that Stem girth increased with increase in amount of bio-slurry manure applied. At harvest, plants treated with bio-slurry at $30 \mathrm{t}$ $\mathrm{ha}^{-1}$ had the biggest stem girth $(2.16 \pm 0.6 \mathrm{~cm})$ followed by plants treated with bio-slurry at $15 \mathrm{tha}^{-1}(2.08 \pm 0.5 \mathrm{~cm})$ The least stem girth $(1.88 \pm 0.6 \mathrm{~cm})$ was recorded for the untreated control plants. None of these results exceeded those of NPK $(2.36 \pm 1.2 \mathrm{~cm})$ but they exceed the control.

Results also clearly indicated that application of bio-slurry at different rates significantly affected the plant height. Highest mean height $(14.18 \pm 9.7 \mathrm{~cm})$ at harvest was recorded where plants treated with bio-slurry at $30 \mathrm{t}$ $\mathrm{ha}^{-1}$. This was followed by $30 \mathrm{t} \mathrm{ha}^{-1}$ with height of $13.65 \pm 9.7 \mathrm{~cm}$. However minimum plant height $(10.54 \pm 5.18$ $\mathrm{cm}$ ) was observed in the control where the plants were treated with no manure. This might be due to the ability of bio-slurry to supply more readily available nutrients required for plant growth. These results are in line with those of Shahabz (2011) who noted that bio-slurry causes increase in plant height of Okra at maturity over the control. The better crop performance in relation to plant height that was obtained in the bio-slurry treatments could be due to the presence of growth promoting factors such as enzymes and hormones that cause development of more buds and a subsequent increase in the number of leaves. It is therefore possible that as the height increased due the uptake of $\mathrm{N}$ in its nitrate form, there was an increase in vegetative growth as indicated by the increase in number of leaves (Callistus \& Anthony, 2014). The highest mean number of leaves $(34.45 \pm 21.0$ leaves) was recorded for plants treated with bio-slurry at $15 \mathrm{t} \mathrm{ha}^{-1}$. However lowest number of leaves (25.79 \pm 12.7 leaves) was recorded for the control plants. Results of mean leaf area show that the highest leaf area of $58.77 \pm 29.8 \mathrm{~cm}^{2}$ was recorded in plots treated with poultry manure at $25 \mathrm{t} \mathrm{ha}^{-1}$ followed by the plants treated with $15 \mathrm{t} \mathrm{ha}^{-1}$ which had mean leaf area of $58.60 \pm 7.5 \mathrm{~cm}^{2}$. The least mean leaf area of $49.05 \pm 29.4 \mathrm{~cm}^{2}$ was recorded for the control. All bio-slurry rates performed better than the control but none performed better that NPK.

Table 2. Mean effect of bio-slurry (BS) on growth and yield parameters of S. aethiopicum

\begin{tabular}{|c|c|c|c|c|c|c|c|}
\hline Treatments & $\begin{array}{l}\text { Stem girth } \\
(\mathrm{cm})\end{array}$ & Height (cm) & $\begin{array}{l}\text { Number } \\
\text { of leaves }\end{array}$ & $\begin{array}{l}\text { Leaf area } \\
\left(\mathrm{cm}^{2}\right)\end{array}$ & $\begin{array}{l}\text { Number of } \\
\text { branches }\end{array}$ & $\begin{array}{l}\text { Marketable } \\
\text { yield }\left(\mathrm{kg} \mathrm{ha}^{-1}\right)\end{array}$ & Harvest Index \\
\hline Control & $\begin{array}{l}0.263 \\
(1.92 \pm 0.6)^{\mathrm{a}}\end{array}$ & $\begin{array}{l}0.974 \\
(10.54 \pm 5.2)^{b}\end{array}$ & $\begin{array}{l}1.360 \\
(25.79 \pm 12.7)^{\mathrm{a}}\end{array}$ & $\begin{array}{l}1.603 \\
(49.05 \pm 29.4)^{\mathrm{a}}\end{array}$ & $\begin{array}{l}0.805 \\
(6.91 \pm 3.7)^{\mathrm{a}}\end{array}$ & $1186.96 \pm 1095.0^{\mathrm{a}}$ & $0.905 \pm 0.05^{\mathrm{a}}$ \\
\hline BS at $5 \mathrm{tha}^{-1}$ & $\begin{array}{l}0.262 \\
(1.93 \pm 0.5)^{\mathrm{a}}\end{array}$ & $\begin{array}{l}0.946 \\
(10.54 \pm 5.8)^{\mathrm{ab}}\end{array}$ & $\begin{array}{l}1.361 \\
(26.70 \pm 13.3)^{\mathrm{a}}\end{array}$ & $\begin{array}{l}1.578 \\
(46.75 \pm 28.9)^{\mathrm{a}}\end{array}$ & $\begin{array}{l}0.804 \\
(6.96 \pm 3.6)^{\mathrm{a}}\end{array}$ & $1554.02 \pm 695.9^{\mathrm{ab}}$ & $0.925 \pm 0.01^{\mathrm{a}}$ \\
\hline BS at $10 \mathrm{tha}^{-1}$ & $\begin{array}{l}0.248 \\
(1.88 \pm 0.6)^{\mathrm{a}}\end{array}$ & $\begin{array}{l}0.912 \\
(9.98 \pm 6.5)^{\mathrm{a}}\end{array}$ & $\begin{array}{l}1.364 \\
(30.26 \pm 29.1)^{\mathrm{a}}\end{array}$ & $\begin{array}{l}1.579 \\
(45.67 \pm 25.3)^{\mathrm{a}}\end{array}$ & $\begin{array}{l}0.787 \\
(7.31 \pm 8.4)^{\mathrm{a}}\end{array}$ & $2153.01 \pm 448.9^{\mathrm{bcd}}$ & $0.919 \pm 0.01^{\mathrm{a}}$ \\
\hline BS at $15 \mathrm{tha}^{-1}$ & $\begin{array}{l}0.306 \\
(2.08 \pm 0.5)^{\mathrm{b}}\end{array}$ & $\begin{array}{l}1.067 \\
(13.55 \pm 8.0)^{\mathrm{cd}}\end{array}$ & $\begin{array}{l}1.476 \\
(34.45 \pm 21.0)^{\mathrm{bc}}\end{array}$ & $\begin{array}{l}1.714 \\
(58.60 \pm 27.5)^{\mathrm{d}}\end{array}$ & $\begin{array}{l}0.871 \\
(8.50 \pm 5.5)^{\mathrm{b}}\end{array}$ & $2002.31 \pm 537.2^{\mathrm{bcd}}$ & $0.922 \pm 0.03^{\mathrm{a}}$ \\
\hline $\mathrm{BS}$ at $20 \mathrm{tha}^{-1}$ & $\begin{array}{l}0.275 \\
(1.95 \pm 0.5)^{\mathrm{a}}\end{array}$ & $\begin{array}{l}1.035 \\
(12.99 \pm 8.1)^{\mathrm{c}}\end{array}$ & $\begin{array}{l}1.434 \\
(31.59 \pm 17.1)^{\mathrm{b}}\end{array}$ & $\begin{array}{l}1.637 \\
(53.85 \pm 45.5)^{\mathrm{abc}}\end{array}$ & $\begin{array}{l}0.814 \\
(7.00 \pm 2.8)^{\mathrm{a}}\end{array}$ & $2564.69 \pm 1216.9^{d}$ & $0.903 \pm 0.05^{\mathrm{a}}$ \\
\hline BS at $25 \mathrm{tha}^{-1}$ & $\begin{array}{l}0.304 \\
(2.02 \pm 0.7)^{b}\end{array}$ & $\begin{array}{l}1.093 \\
(14.18 \pm 9.7)^{\mathrm{d}}\end{array}$ & $\begin{array}{l}1.472 \\
(33.47 \pm 24.1)^{\mathrm{bc}}\end{array}$ & $\begin{array}{l}1.702 \\
(58.77 \pm 29.8)^{\mathrm{d}}\end{array}$ & $\begin{array}{l}0.903 \\
(8.87 \pm 6.2)^{\mathrm{bc}}\end{array}$ & $1918.93 \pm 625.6^{\mathrm{bc}}$ & $0.902 \pm 0.04^{\mathrm{a}}$ \\
\hline $\mathrm{BS}$ at $30 \mathrm{tha}^{-1}$ & $\begin{array}{l}0.337 \\
(2.16 \pm 0.6)^{c}\end{array}$ & $\begin{array}{l}1.108 \\
(13.65 \pm 9.7)^{d}\end{array}$ & $\begin{array}{l}1.435 \\
(29.47 \pm 22.8)^{\mathrm{b}}\end{array}$ & $\begin{array}{l}1.689 \\
(57.53 \pm 29.4)^{\mathrm{cd}}\end{array}$ & $\begin{array}{l}0.879 \\
(7.61 \pm 6.1)^{\mathrm{bc}}\end{array}$ & $2249.29 \pm 521.8^{\mathrm{cd}}$ & $0.917 \pm 0.01^{\mathrm{a}}$ \\
\hline NPK (25:5:5) & $\begin{array}{l}0.327 \\
(2.36 \pm 1.2)^{\mathrm{bc}}\end{array}$ & $\begin{array}{l}1.027 \\
(13.24 \pm 9.3)^{\mathrm{c}}\end{array}$ & $\begin{array}{l}1.495 \\
(37.12 \pm 23.7)^{\mathrm{c}}\end{array}$ & $\begin{array}{l}1.662 \\
(60.0 \pm 45.1)^{\text {bcd }}\end{array}$ & $\begin{array}{l}0.916 \\
(9.79 \pm 7.0)^{\mathrm{c}}\end{array}$ & $3434.20 \pm 297.8^{\mathrm{e}}$ & $0.936 \pm 0.01^{\mathrm{a}}$ \\
\hline Mean & 0.290 & 1.020 & 1.425 & 1.646 & 0.848 & 2132.929 & 0.916 \\
\hline S.E.D. & 0.014 & 0.026 & 0.024 & 0.030 & 0.033 & 278.244 & 0.018 \\
\hline F. pr & $<0.001$ & $<0.001$ & $<0.001$ & $<0.001$ & $<0.001$ & $<0.001$ & 0.568 (NS) \\
\hline L.S.D. $(\alpha=0.05)$ & 0.028 & 0.050 & 0.048 & 0.059 & 0.066 & 568.251 & 0.038 \\
\hline Treatment*season & $<0.001$ & $<0.001$ & $<0.001$ & $<0.001$ & $<0.001$ & 0.003 & 0.510 \\
\hline C.V. $\%$ & 43.9 & 22.6 & 15.4 & 16.5 & 24.72 & 22.6 & 3.5 \\
\hline
\end{tabular}

Note. Means of original data are put in brackets and means of transformed data are outside the brackets, NS: Not significant, Means with similar letters are not statistically significantly different at $p \leq 0.05$ based on the Duncan's Multiple Range Test. 
Results number of branches show that highest mean number of branches of ( $8.87 \pm 6.2$ branches) was recorded for plants treated with bio-slurry at $25 \mathrm{t} \mathrm{ha}^{-1}$ while the lowest number of branches $(6.91 \pm 3.72$ branches) was recorded for the untreated control plants. Marketable yield and harvest index of S. aethiopicum as influenced by bio-slurry are also shown in Table 2. The mean across seasons indicates that the highest marketable yield of $2564.69 \pm 1216.9 \mathrm{~kg} \mathrm{ha}^{-1}$ was produced by the application of bio-slurry at the rate of $20 \mathrm{tha}^{-1}$. This was followed by marketable yield of $2249.29 \pm 521.8 \mathrm{~kg} \mathrm{ha}^{-1}$ for bio-slurry at a rate of $30 \mathrm{t} \mathrm{ha}^{-1}$. Marketable yield was least in control plots which had $1186.96 \pm 1095.0 \mathrm{tha}^{-1}$.

All treatments significantly differed in terms of mean stem girth, plant height, number of leaves, mean leaf area and number of branches at $p<0.05$. The marketable yield was also significantly different $(p<0.05)$ between the control and all the bio-slurry treatments. The application of bio-slurry manure significantly increases the yield of $S$. aethiopicum an effect that can be attributed to the fact that bio-slurry does stimulate plant growth and the general bulk of the vegetative parts of the crop (Gurung, 2007). In addition the highest harvest index of $0.925 \pm 0.01$ was recorded $5 \mathrm{t} \mathrm{ha}^{-1}$ followed by $0.922 \pm 0.03$ at $15 \mathrm{t} \mathrm{ha}^{-1}$. The least harvest index was $0.905 \pm 0.05$ and it was recorded for there was at $15 \mathrm{t} \mathrm{ha}^{-1}$. Similarly there was also a significant difference $(\mathrm{p}<0.05)$ in the harvest index in both seasons.

Similar to poultry manure the regression analysis of marketable yield as a dependable variable and bio-slurry manure rates as the regressor showed that increase in yield of $S$. ethiopicum produced was affected by the bio-slurry manure applied. This was significant at the coefficient of multiple determinations $\left(\mathrm{R}^{2}\right)$ of $77.0 \%$. Figure 2 indicated that largest yield responses to bio-slurry manure occur with the first increments of applied manure. At this stage gains in economic returns per kg of manure are also greatest. The returns are lower as the manure rate approaches the economic optimum (when the cost of additional manure is equal to the value of the associated yield increase. When the derivative of the quadratic equation for total yield $y=-2.371 x^{2}+102.0 x+$ 1186 was solved, it resulted in a maximum poultry manure rate of $21.51 \mathrm{t} \mathrm{ha}^{-1}$. The optimum bio-slurry rate was therefore predicted to be at $21.51 \mathrm{tha}^{-1}$. This predicted application is between $20 \mathrm{tha}^{-1}$ and $25 \mathrm{tha}^{-1}$ which were associated with higher stem girth, plant height, leaf area and yield respectively. These results are however not in line with the recommendation of Warnars and Oppenoorth (2014) who recommended applying around 10 to $20 \mathrm{t}$ $\mathrm{ha}^{-1}$ of bio-slurry onto the crop to significantly increase the yield and nutrient uptake of plants.

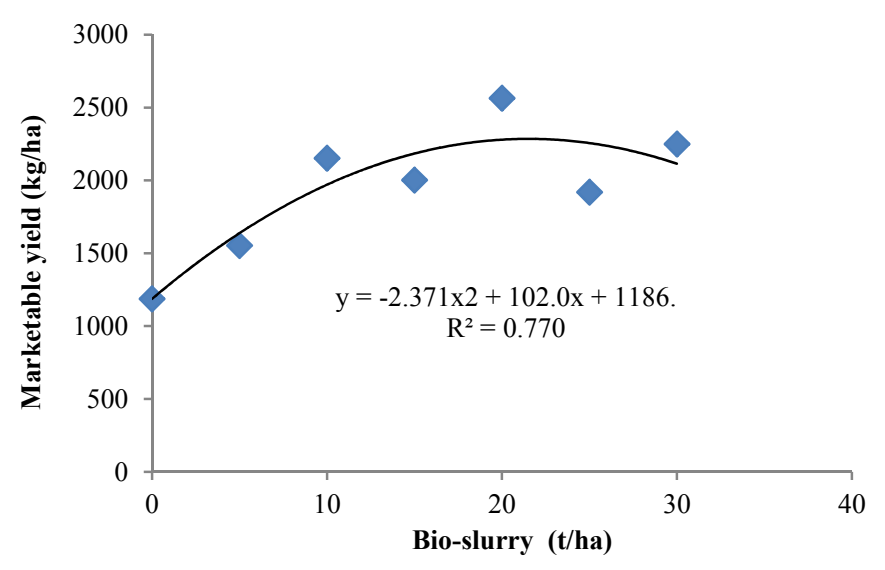

Figure 2. Effect of Bio-slurry on the yield of S. aethiopicum

\section{Conclusion}

The results of this study illustrate that, in general, use of organic manures especially poultry manure and bio-slurry can lead to better performance and greater yields $S$. aethiopicum than not using fertilizers. From the result obtained in this study, it can therefore be concluded that the use of poultry manure and Bio-slurry manure in S. aethiopicum production is desirable as these organic fertilizers significantly increased marketable yields of the $S$. aethiopicum by increasing the number of leaves and branches. The leaf area and harvest index were also increased. From the results obtained, the research hypothesis that there is no significant difference in the response of $S$. aethiopicum to different levels of bio-slurry and poultry manure is rejected and hence concluded that there is a difference in the response of $S$. aethiopicum to different levels of bio-slurry and poultry manure. 
Since the objective was to determine optimum manure rates for $S$. aethiopicum production, it can be concluded that the application of $24.19 \mathrm{tha}^{-1}$ of decomposed poultry manure or $21.51 \mathrm{t} \mathrm{ha}^{-1}$ of bio-slurry are recommended for optimum S. aethiopicum production. However for the farmer to make economic sense, it can recommended to use $20 \mathrm{tha}^{-1}$ and $10 \mathrm{tha}^{-1}$ of sole poultry manure and bio-slurry manure respectively.

\section{Acknowledgements}

This work was financed by CGIAR under the Humidtropics program cluster 4 project led by International Institute of Tropical Agriculture (IITA). Special thanks go to the National Facilitator R4D platforms, the chairperson of Mukono/ Wakiso platform including Uganda Christian University, Farmgain Africa, Makerere University, College of Agriculture and Environment Science (MUK) and Mukono Zonal Agricultural Research Institute (MUZARDI). The efforts of the staff of the Department of Agricultural and Biological Sciences, Uganda Christian University are also highly appreciated.

\section{References}

Abolusoro, S. A., Abolusoro, P. F., Mathew, F. O., \& Izuogu, N. B. (2013). Effects of Organic and Inorganic Manures on the Growth Attributes of Root-knot Nematode (Meloidogyne incognita) Infected Ethopian Egg Plant (Solanum aethiopicum). World Journal of Agricultural Research, 1(6), 104-107.

Ahmad, T., Shah, S. T., Ullah, F., Ghafoor, F., \& Anwar, U. (2017). Effect of organic fertilizer on growth and yield of coriander. Int. J. Agri and Env. Res., 3(1), 116-120.

Ajayi, O. C., Akinnifesi, F. K., Sileshi, G., \& Kanjipite, W. (2009). Labour inputs and financial profitability of conventional and agroforestry-based soil fertility management practices in Zambia. Agrekon, 3, 276-292. https://doi.org/10.1080/03031853.2009.9523827

Aminul, H. (2013). Bio Slurry Ultimate Choice of Biofertilizer (Vol. 2, p. 738). Open Access Scietific Reports, Bangladesh.

Bationo, A., Waswa, B., Kihara, J., \& Kimetu, J. (2006). Advances in integrated soil fertility management in sub Saharan Africa: Challenges and opportunities. Nutrient Cycling in Agroecosystems, 79, 1-2.

Bonsu, K. O., Shipper, R. R., Nkasah, G. O., Owosu, E. O., \& Orchard, J. E. (2000). Gboma eggplant a potential new export crop for Ghana (p. 14). Book of Abstract Fifth International Solanacae Conference. Botanical Garden of Nijonegan, July 23-29, 2000.

Environment Agency. (2010). How to comply with your environmental permit for intensive farming. Almondsbury, Bristol. Retrieved from http://www.environment-agency.gov.uk

Farhad, W., Saleem, M. F., Cheema, M. A., \& Hammad, H. M. (2009). Effect of poultry manure levels on the productivity of sring maize. The Journal of Animal and Plant Sciences, 19(3), 122-125.

Gomez, A. K., \& Gomez, A. A. (1984). Statistical Procedures for Agricultural Research. John Wiley.

Ijoyah, M. O., \& Sophie, N. L. (2009). Effects of different levels of decomposed poultry manure on yield of cabbage (Brassica oleraceae L.) at anse Boileau, Seychelles. Journal of Tropical Agriculture, Food, Environment and Extension, 8(1), 20-23.

Lester, R. N., \& Seck, A. (2004). Solanum aethiopicum L. In G. J. H. Grubben, \& O. A. Denton (Eds.), PROTA 2: Vegetables/Légumes [CD-Rom]. PROTA, Wageningen, Netherlands.

McCarter, S. M., Jaworski, C. A., \& Johnson, A. (1976). Soil fumigation effect on early blight of tomato transplants. Phytopathology, 66(9), 1122-1124. https://doi.org/10.1094/Phyto-66-1122

Mugwe, J., Mugendi, D., \& Kungu, J. (2007). Effect of plant biomass, manure and inorganic fertiliser on maize in the central highlands of Kenya. African Crop Science Journal, 15(3), 111-126.

Nakanwagi, M. J., Sseremba, G., Masanza, M., \& Kizito, E. B. (2018). Performance of Solanum aethiopicum Shum group accessions under Repetitive Drought Stress. Journal of Plant Breeding and Crop Science, 10(1), 13-20. https://doi.org/10.5897/JPBCS2017.0690

Nompumelelo, M. A. (2008). Influence of organic fertlisers on the yield and quality of cabbageand carrots. Doc Stoc Web Site.

Oyewole, C. I., Haruna, O., \& Omale, R. (2012). Response of Tomato (Lycopersicon esculentum): Growth and Yield, to Rates of Mineral and Poultry Manure Application in the Guinea Savanna Agro-ecological Zone in Nigeria. Journal of Biology, Agricultureand Healthcare, 2(2), 46-56. 
Sanchez, P. A., \& Jama, B. A. (2002). Soil fertility replenishment takes off in East and southern Africa. In B. Vanlauwe, N. Diels, N. Sanginga, \& R. Merkx (Eds.), Integrated Nutrient Management in Sub-Saharan Africa: From Concept to Practice (pp. 23-46). CABI.

Sanchez, P. A., Shepherd, K. D., Soule, M. J., Place, F. M., Buresh, R. J., Izac, A. M. N., \& Woomer, P. L. (1997). Soil fertility replenishment in Africa: An investment in natural resource capital. Replenishing Soil Fertility in Africa (pp. 1-46).

Sánchez-Mata, M. C., Yokoyama, W. E., Hong, Y. J., \& Prohens, J. (2010). $\alpha$-Solasonine and $\alpha$-solamargine contents of gboma (Solanum macrocarpon L.) and scarlet (Solanum aethiopicum L.) eggplants. Journal of Agricultural and Food Chemistry, 58(9), 5502-5508. https://doi.org/10.1021/jf100709g

Schippers, R. R. (2000). African indigenous vegetables: An overview of the cultivated species (p. 211).

Smith, F. I., \& Eyzaguirre, P. (2007). African leafy vegetables: Their role in the world health organization's global fruit and vegetables initiative.

Ssekabembe, C. K., \& Odong, T. L. (2009). Effect of spacing and thinning date on the yield of broadcast nakati. African Crop Science Conference Proceedings (Vol. 9, pp. 135-140). Kampala, Uganda: African Crop Science Society.

Ssekabembe, C., Bukenya, C., \& Nakyagaba, W. (2003). Traditional knowledge and practices in local vegetable production in central Uganda. African Crop Science Conference Procedings. Retrieved May 28, 2015, from http://www.acss.ws/Upload/XML/Research/17.pdf

Sseremba, G., Kabod, P. N., Kasharu, A. K., Jaggwe, J. N., Masanza, M., \& Kizito, E. B. (2017a). Diversity and distribution of African indigenous vegetable species in Uganda. International Journal of Biodiversity and Conservation, 9(11), 334-341. https://doi.org/10.5897/JJBC2017.1120

Sseremba, G., Tongoona, P., Eleblu, J. S. Y., Danquah, E. Y., Kabod, P. N., \& Kizito, E. B. (2017b). Morphological distinctiveness between Solanum aethiopicum Shum group and its progenitor. Journal of Plant Breeding and Crop Science, 9(8), 118-129.

Sseremba, G., Tongoona, P., Eleblu, J. S. Y., Danquah, E. Y., Kaweesi, T., Baguma, Y., ... Kizito, E. B. (2018). Stability of Solanum aethiopicum Shum accessions under varied water deficit stress levels and identification of pertinent breeding traits for resistance to water shortage. Euphytica, 214(11), 1-11. https://doi.org/ 10.1007/s10681-017-2097-8

Thorsen, M. K., \& Stephen, W. (2010). Kelp (Laminaria digitata) increases germination and affects rooting and plant vigour in crops and native plants from an arable grassland in the Outer Hebrides, Scotland. Springer Science+Business Media, 2010, 239-246. https://doi.org/10.1007/s11852-010-0091-6

Warnars, L., \& Harrie, O. (2014). Bioslurry a sumpreme fertiliser: Astudy on bioslurry results and uses. Hivos.

\section{Copyrights}

Copyright for this article is retained by the author(s), with first publication rights granted to the journal.

This is an open-access article distributed under the terms and conditions of the Creative Commons Attribution license (http://creativecommons.org/licenses/by/4.0/). 